\section{Rooted Cutting Establishment in Media Containing Wetting Agent}

\author{
N.R. Bhat ${ }^{1}$, Thomas L. Prince ${ }^{1}$, Harry K. Tayama ${ }^{2}$, and \\ Stephen A. Carver ${ }^{3}$ \\ Department of Horticulture, The Ohio State University, Columbus, \\ $\mathrm{OH} 43210$
}

Additional index words. Aqua-Gro ' $\mathrm{G}$ ', phytotoxicity, surfactant, Dendranthema
$\times$ grandiflora, Euphorbia pulcherrima, Impatiens wallerana, Pelargonium hortorum

Wetting agents used in growing media regulate moisture reserves and improve aeration and nutrient availability (Pelishek et al., 1962). Manufacturers of growing media and growers who blend their own mix incorporate wetting agents to ensure rapid and uniform penetration of water and fertilizer solutions throughout the medium (Powell, 1986; Valoris et al., 1969).

There is not a wealth of published data documenting the influence of wetting agents on development of potted floral crops. This study was conducted to examine the establishment and growth of rooted cuttings of potted 'Bright Golden Anne' chrysanthemum [Dendranthema $\times$ grandiflora (Ramat) Kitamura], 'Your's Truly' zonal geranium

Received for publication 28 Sept. 1990. Manuscript no. 84-90. Salaries and research support were provided by state and federal funds appropriated to The Ohio State Univ., Ohio Agricultural Research and Development Center, Columbus. Financial support was received from the Aquatrols Corp. of America, Pennsauken, N.J., and plant materials were courtesy of Yoder Brothers, Barberton, Ohio; Paul Ecke Poinsettia, Encinitas, Calif.; Mikkelsen Greenhouses, Ashtabula, Ohio; and Deans Greenhouse, Westlake, Ohio. Plastic flats were donated by Sandusky Plastics, Sandusky, Ohio. The cost of publishing this paper was defrayed in part by the payment of page charges. Under postal regulations, this paper therefore must be hereby marked advertisement solely to indicate this fact.

${ }^{1}$ Postdoctoral Fellow.

${ }^{2}$ Professor.

${ }^{3}$ Research Associate.
[Pelargonium $\times$ hortorum L.H. Bailey], New Guinea impatiens [Impatiens wallerana (Engl. \& Warb.) Hook.f.], and 'Brilliant Diamond' poinsettia [Euphorbia pulcherrima (Willd. ex. Klotzsch)] in media blended with varying concentrations of Aqua-Gro ' $G$ ' [polyoxyethylene esters of cyclic acid $(47 \%)$ and polyoxyethylene ethers of alkylated phenols (47\%) and silicone antifoam emulsion (6\%); Aquatrols Corp. of America, Pennsauken, N.J.].

The medium used consisted of equal proportions (v/v) of sphagnum peat (Fisons Horticulture, Vancouver, Canada) and vermiculite (Grace Sierra, Fogelsville, Pa.) blended with varying concentrations of AquaGro ' $\mathrm{G}$ ' $(0,0.23,0.47,0.94,1.88$, or 3.76 $\mathrm{kg}$ a.i. $/ \mathrm{m}^{3}$; manufacturer's recommended rate is $0.36 \mathrm{~kg} \cdot \mathrm{m}^{-3}$ ) in a cement mixer for $5 \mathrm{~min}$. Plastic flats with 48 cells (0.3 liter each or $8 \times 6 \times 6 \mathrm{~cm})$ were filled with one of the above Aqua-Gro ' $G$ '-amended media and irrigated thoroughly. Rooted cuttings of each of the above species were planted, one per cell, on 18 Jan. (chrysanthemum), 18 Feb. (geranium), 20 Mar. (New Guinea impatiens), or 17 May 1989 (poinsettia) and irrigated again. Plants were maintained at $15.5 \mathrm{C}$ (night) and irrigated with a solution containing $200 \mathrm{mg}$ N/liter from Peters' 20N-4.3P16.6K (Grace Sierra). Each plant species was subject to six treatments replicated three times in a randomized block design. Each replication consisted of 48 cuttings.

Cuttings were observed daily to record establishment (percentage of cuttings that sur- vived following planting). Plant height, spread (average of width in two directions), and root growth were recorded 4 weeks after planting. A six-point rooting scale $(5=$ profuse root growth reaching the bottom and all four sides of the cell to $0=$ no roots or dead roots at the base of the cutting) was used to evaluate root growth. The experiments were repeated on 14 Mar. (chrysanthemum), 2.5 Apr. (geranium), 30 May (New Guinea impatiens), and 30 May 1989 (poinsettia) under similar conditions described above. Since there were no differences between experiments, data from the two sets of experiments were combined and tested using analysis of variance with planned orthogonal comparisons.

Chrysanthemum. All rates had no affect on the establishment, final height, and root growth of chrysanthemum cuttings.

Geranium. Aqua-Gro ' $G$ ' at any rate in the growing media had no influence on cutting establishment or root growth (Table 1).

New Guinea impatiens. New Guinea impatiens exhibited the most sensitivity (Table 1). Although the initial establishment of cuttings was not affected, subsequent shoot and root growth was severely hampered at rates higher than $0.94 \mathrm{~kg} \cdot \mathrm{m}^{-3}$. Severely restricted root growth was observed.

Poinsettia. Cuttings established well $(100 \%)$ in all concentrations tested (Table 1). However, plant height, spread, and root growth were linearly reduced with rate.

At relatively high concentrations $\left(2 \mathrm{~kg} \cdot \mathrm{m}^{-3}\right)$, surfactants such as Aqua-Gro ' $G$ ' have been shown to disrupt membrane integrity (A.R. Templeton, 1988, personal communication). Therefore, it is very important to consider the safety margins when using this chemical on sensitive crops.

\section{Literature Cited}

Pelishek, R.E., J. Osborn, and J. Letey. 1962. The effects of wetting agents on infiltration. Proc. Amer. Soil. Sci. Soc. 26:595-598.

Powell, D. 1986. Wetting agents-Tools to control water movement, Ohio Florists' Assn. Bul. 681:6-8.

Valoris, N., J. Letey, and J.F. Osbom. 1969. Adsorption of nonionic surfactants by soil materials. Proc. Amer. Soil Sci. Soc. 33:345-348.

Table 1. Growth of 'Bright Golden Anne' chrysanthemum, 'Your's Truly' geranium, New Guinea impatiens, and 'Brilliant Diamond' poinsettia rooted cuttings in soilless growing medium amended with the wetting agent Aqua-Gro 'G'.

\begin{tabular}{|c|c|c|c|c|c|c|c|c|c|c|}
\hline \multirow[b]{2}{*}{$\begin{array}{l}\text { Aqua-Gro } \\
\left(\mathrm{kg} \text { a.i. } / \mathrm{m}^{3}\right)\end{array}$} & \multicolumn{2}{|c|}{ Chrysanthemum } & \multicolumn{2}{|c|}{ Geranium } & \multicolumn{3}{|c|}{ New Guinea impatiens } & \multicolumn{3}{|c|}{ Poinsettia } \\
\hline & $\begin{array}{l}\mathrm{Ht} \\
(\mathrm{cm})\end{array}$ & $\begin{array}{l}\text { Spread } \\
(\mathrm{cm})\end{array}$ & $\begin{array}{c}\mathrm{Ht} \\
(\mathrm{cm})\end{array}$ & $\begin{array}{c}\text { Spread } \\
(\mathrm{cm})\end{array}$ & $\begin{array}{l}\mathrm{Ht} \\
(\mathrm{cm})\end{array}$ & $\begin{array}{c}\text { Spread } \\
(\mathrm{cm})\end{array}$ & $\begin{array}{c}\text { Rooting } \\
\text { scale }^{z}\end{array}$ & $\begin{array}{l}\mathrm{Ht} \\
(\mathrm{cm})\end{array}$ & $\begin{array}{c}\text { Spread } \\
(\mathrm{cm})\end{array}$ & $\begin{array}{c}\text { Rooting } \\
\text { scale }\end{array}$ \\
\hline Control & 33.5 & 12.3 & 12.7 & 11.3 & 18.5 & 17.7 & 4.6 & 25.3 & 21.6 & 4.4 \\
\hline 0.23 & 35.1 & 12.4 & 12.9 & 11.7 & 18.5 & 18.3 & 4.2 & 23.5 & 22.6 & 4.4 \\
\hline 0.47 & 31.9 & 12.3 & 13.0 & 11.1 & 16.9 & 16.4 & 3.7 & 22.5 & 21.4 & 4.3 \\
\hline 0.94 & 34.7 & 13.1 & 13.2 & 11.0 & 15.3 & 15.2 & 3.3 & 19.0 & 20.1 & 4.2 \\
\hline 1.88 & 32.1 & 11.9 & 12.0 & 10.8 & 13.6 & 14.8 & 2.4 & 19.9 & 19.3 & 4.0 \\
\hline 3.76 & 30.8 & 11.7 & 12.0 & 10.2 & 10.3 & 12.7 & 1.8 & 16.0 & 18.8 & 3.9 \\
\hline \multicolumn{11}{|l|}{ Planned comparisons } \\
\hline Control vs. others & NS & NS & NS & NS & $* *$ & $* *$ & $* *$ & $* *$ & NS & $* *$ \\
\hline Rate & NS & $\mathrm{L}^{*}$ & $\mathrm{~L}^{*}$ & $\mathrm{~L}^{*}$ & $\mathrm{~L}^{* *}$ & $\mathrm{~L}^{* *}$ & $\mathrm{~L}^{* *} \mathrm{Q}^{* *}$ & $\mathrm{~L}^{* *}$ & $\mathrm{~L}^{* *}$ & $\mathrm{~L}^{* *}$ \\
\hline
\end{tabular}

${ }^{2}$ Rooting scale: $5=$ profuse root growth to bottom and all sides of cell, $4=$ moderate growth to bottom and all sides of cells, 3 $=$ root growth to bottom and one side, $2=$ sparse root growth to the bottom of cell, 1 = restricted root growth only at base of cutting, $0=$ no living roots at base of cutting.

$*, * *,{ }^{N S}$ Significant at $P=0.05$ or 0.01 or nonsignificant; linear (L), quadratic (Q). 